\title{
Erkek Meme Lezyonlarının Patolojisi: Vaka Serisi ve Literatür Tarama
}

\author{
Pathology of Male Breast Lesions: Case Series and \\ Literature Review
}

Pınar GELEPLi' ${ }^{1}$, Salih CELEPLi் ${ }^{2}$, İrem BİGAT ${ }^{3}$, Sema HÜCÜMENOĞLU ${ }^{4}$

'Ankara Eğitim ve Araştırma Hastanesi, Patoloji Bölümü,

${ }^{2}$ Gülhane Eğitim ve Araştırma Hastanesi, Genel Cerrahi,

${ }^{3}$ TOBB Ekonomi ve Teknoloji Üniversitesi, Biyomedikal Mühendisliği,

${ }^{4}$ Ankara Eğitim ve Araştırma Hastanesi, Patoloji Bölümü,

Yazışma Adresi

Correspondence Address

\section{Pinar GELEPLi}

Ankara Eğitim ve Araştırma Hastanesi, Patoloji Bölümü, Ankara, Türkiye

E-posta: pcelepli@yahoo.com
Geliş tarihi \Received : 14.07 .2020 Kabul tarihi \Accepted : 21.08.2020 Elektronik yayın tarihi $\quad: 12.07 .2021$ Online published

Bu makaleye yapilacak atıf: Cite this article as:

Celepli P, Celepli S, Bigat I, Hücümenoğlu S. Erkek meme lezyonlarmm patolojisi: Vaka serisi ve literatür tarama. Akd Tip D 2021; 7(2):301-306

Pinar CELEPLi ORCID ID: 0000-0001-7643-6263 Salih CELEPLI ORCID ID: 0000-0002-3596-7938 İrem BİGAT ORCID ID: 0000-0003-0067-1675 Sema HÜCÜMENOĞLU ORCID ID: 0000-0002-6898-4101

\section{ÖZ}

Amaç: Meme kanseri, kadınlarda en sık görülen ve en sık ölüme neden olan kanserdir. Erkek meme kanserleri nadir görülür ve tüm meme kanserlerinin \% 1'den azını oluşturur. Nadir olması nedeniyle çok az çalışma vardır ve spesifik erkek standart protokolü yapılamamıştır. Erkek meme kanserleri ile ilgili güncel tedavi yaklaşımı ve prognostik faktörler meme kanserli kadınlara yapılan çalışmalardan çıkarılmıştır. Erkeklerde meme kanserleri daha ileri yaşta ve tanı anında ileri evrede saptanmaktadır. Bu çalışmada amaç erkeklerde saptanan meme lezyonlarının profilini çıkarmak, kanserli olguları klinik ve patolojik olarak değerlendirmektir.

Gereç ve Yöntemler: Bu çalışmada, jinekomasti ve meme karsinom vakalarını da içeren erkek meme lezyonlarını retrospektif olarak inceleyerek 5 yıllık deneyimimizi sunuyoruz.

Bulgular: Hastanemiz Ocak 2015-Ocak 2020 tarihleri arasında retrospektif olarak; 6 invaziv karsinom, 1 intraduktal papillom, 3 pilomatriksoma, 1 lipomatozis ve 32 jinekomasti olmak üzere toplam 43 erkek meme lezyonu tespit ettik. Malign lezyonlar 4- 8. dekadlarda görüldü. Malign lezyonlar Grade II ve Grade III olarak izlendi. Tümör boyutu en küçük 1,1 cm en büyük 3,0 cm olarak tespit edildi. Her bir vakada farklı düzeyde hormon reseptör ekspresyonu izlendi.

Sonuç: Erkek meme tümörleri sıklıkla jinekomasti gibi benign hastalıklar ile karışabildiği için, hasta ve hekimler tarafindan göz ardı edilebilir. Bu yüzden tanı konduğu anda ileri evreye ulaşan meme tümörleri ile karşımıza çıkabildiği için daha dikkatli yaklaşım gerekmektedir. Erkeklerde tespit edilen lezyonların çoğu benign olmasına karşın ileri yaşta memede ele gelen kitle varlığında malignite ön planda düşünülmelidir.

Anahtar Sözcükler: Erkek Meme Karsinomu, Erkek Meme Lezyonları, Hormon Profili

\begin{abstract}
Objective: Breast cancer is the most common cancer that causes death in women. Male breast cancers are rare and make up less than $1 \%$ of all breast cancers. Therefore, there are very few studies and no specific male standard protocol has been made. The current treatment approach and prognostic factors for male breast cancers have been removed from studies on women with breast cancer. In men, breast cancers are detected at an advanced age and at an advanced stage. Purpose of this study is to profile breast lesions detected in men and to evaluate cancer cases clinically and pathologically.

Material and Methods: We present our 5-year experience by retrospectively examining male breast lesions including cases of gynecomastia and breast carcinoma.

Results: Retrospectively between January 2015-January 2020 in our hospital; we detected 43 male breast lesions, including 6 invasive carcinomas, 1 intraductal papilloma, 3 pilomatrixoma, 1 lipomatosis and 32 gynecomastia. Malignant lesions were seen in the 4-8th decades. Malignant lesions were Grade II and Grade III. Tumour size was determined as the smallest $1.1 \mathrm{~cm}$ and the largest 3.0 $\mathrm{cm}$. Different levels of hormone receptor expression were observed in each case.

Conclusion: Since male breast tumours can often be confused with benign diseases, they can be ignored. Therefore, a more careful approach is required since it can be encountered with breast tumours that reach advanced stage during diagnosis. Although most of the lesions detected in men are benign, malignancy should be considered at the forefront in the presence of a mass in the breast at an advanced age.
\end{abstract}

Keywords: Male Breast Carcinoma, Male Breast Lesions, Hormone Profile 


\section{GİRIŞ}

Erkek meme lezyonları, nadir olup kadınlara kıyasla bazı önemli histolojik ve fizyolojik farklllıklar içermektedir. Püberte öncesi kadın ve erkekte meme gelişimi benzerdir. Pübertede östrojen stimülasyonu olmadığı için erkek memesinde duktal yapılar gelişir fakat lobüler yapılar büyümez ve nadir olgularda Terminal Duktal Lobüler Ünite (TDLU) bulunabilir. Bundan dolayı, erkeklerde lobüler lezyonlar ve fibroadenomlar çok ender görülür. Kadınlarda meme lezyonlarının çoğunun TDLU'den kaynaklanması nedeniyle daha sık lezyonla karşılaşmaktayız (1).

Jinekomasti, erkek memesinin en sık görülen lezyonudur. Memenin duktal ve mezenkimal elemanların proliferasyonu olup, androjen ve östrojen arasındaki dengesizlikten kaynaklanır. Maternal östrojenlere maruziyet sonucu yenidoğanların çoğunda görülür ve haftalar-aylar içinde kendiliğinden düzelir. Erişkin populasyonda altta yatan bir hastalığın belirtisi olabilir. Artmıs serum östrojen seviyesi (karaciğer hastalığı, obezite, ekzojen östrojen tedavi), azalmış serum androjen seviyesi (Klinefelter sendromu, hipogonadizm, hipofizer yetmezlik), ilaç kullanımı (spironolakton, finasterid, siklik antidepresanlar), alkol, heroin ve esrar ile ilişkili olabileceği gibi, vakaların \%61'i idiyopatik olarak bildirilmiştir (2-4). Histolojik olarak lezyonun süresine bağlı değişkenlik gösteren florid ve fibröz olmak üzere 2 paterni vardır. Vakaların çoğunda 2 patern birlikte bulunur. Florid paternde, yüksek sellülarite gösteren fibroblastik stromayla birlikte çok sayıda tomurcuklanan duktuslar görülür. Fibröz tipte, artmış stromal fibrozis ile beraber minimal duktal proliferasyon vardır. Florid tip sıklıkla 4 aydan kısa süredir var olan jinekomastilerde görülürken, fibröz tip bir yıldan uzun süredir var olan jinekomastilerde gözlenir (2-4).

Erkek meme kanserleri, \%0,1-1 oranında görülme sıklığı ile çok nadir olarak izlenmektedir (5). Son ylllarda insidansı artmasına rağmen, erkek meme kanseri odaklı temel ve klinik araştırmalar sınırlı olup mevcut verilerin çoğunluğu gözlemsel retrospektif çalışmalardan kaynaklanmaktadır (6). Innidansdaki artışın, gelişmiş ülkelerde artan obezite oranlarının bir yansıması olabileceği tahmin edilmektedir (7). Kadınlarda meme kanseri bimodal dağılım göstermesine karşın erkeklerde ileri yaşlarda (70 yaş civarında) pik yapmaktadır (8). Etyoloji tam olarak bilinmemekle birlikte, testiküler hasar ve infertilite gibi hipoandrojenizm, karaciğer hastalığı ve obezite gibi hiperöstrenizme bağlı hormonal dengesizlikler risk artışına neden olabilmektedir. Klinefelter sendromlu (47XXY) erkeklerde meme kanseri riskinin arttığı bilinmektedir. Pozitif aile öyküsü olan erkeklerde meme karsinom riskinin arttı̆̆ı ve çoğunun BRCA 2 gen mutasyonu ile birlikteliği görülmüştür (9). Son zamanlarda CHEK2, PALB2, Androjen reseptörü ve CYP17 gibi diğer germ-line mutasyonlar ile ilişkili olabileceği bildirilmektedir. Çoğu çalışmada jinekomasti ile meme karsinom arasında ilişki bulunamamışır $(10,11)$.
Bu çalışmanın amacı, Ankara SUAM Patoloji bölümünde raporlanan benign ve malign erkek meme lezyonlarını histolojik ve immünhistokimyasal özellikleri ile birlikte değerlendirmektir.

\section{GEREÇ VE YÖNTEMLER}

Hastanemiz Patoloji bölümünde 5 yıllık (Ocak 2015- Ocak 2020) erkek meme lezyonları retrospektif olarak tarandı. Ameliyat geçirmiş 43 erkek meme lezyonun (37 benign ve 6 malign) kayıtlarına ulaşıldı. Tüm vakaların H\&E boyalı kesitleri gözden geçirildi ve malign lezyonlar immünhistokimyasal olarak değerlendirildi. Veriler Microsoft Excel kullanılarak toplandı. Olgular klinik, demografik ve immünhistokimyasal açıdan değerlendirildi. Çalışma 1964 Helsinki Bildirisi'nde belirtilen etik standartlarına göre yapıldı. Çalışmamızda araştırma ve yayın etiğine uyulmuştur. Bu çalışma için Etik Komite Onayı Sağlık Bakanlığı Ankara Eğitim ve Araştırma Hastanesi Klinik Araştırmalar Etik Kurul Başkanlığından E-20 sayılı 250 no'lu çalışma olarak 21.04.2020 tarihinde alınmıştır.

\section{BULGULAR}

Cerrahi olarak opere edilen toplam 43 meme eksizyon materyali değerlendirildi. Lezyonların dağılımı: 1 lipomatozis, 3 pilomatriksoma, 1 intraduktal papillom, 32 jinekomasti ve 6 invaziv karsinom olarak tespit edildi. Hastaların tümü erkek, 34'ü genel cerrahi, 9 jinekomastili hasta plastik cerrahi bölümünde opere edildi.

Erkek meme lezyonu saptanan hasta yaşları 15-75 arasında değişmektedir. Jinekomasti 40 yaş altı gençlerde en sık saptanan lezyon iken, invaziv karsinom vakalarının biri hariç 40 yaş üzerindeydi. Tüm meme lezyonlarında ele gelen kitle ve estetik rahatsılık şikayeti mevcut olup, klinik ve radyolojik olarak değerlendirildi.

Hastane kayıtlarından jinekomastili hastaların klinik öyküleri incelendi ve Familyal ailevi Akdeniz ateşi (FMF), Klinefelter sendromu, ankilozan spondilit, epilepsi, hipertansiyon ve obezite gibi hastalıklar saptandı. Hasta yaşları 15-65 arasında değişmekte ve 7'si 40 yaş üstündedir. Toplam 32 jinekomastili hastanın 18'i bilateral, 8’i sağ meme ve 6'sı sol meme olarak tespit edildi. Hastalar ele gelen kitle ve estetik rahatsızlı nedeniyle opere edildi. Histopatolojik olarak jinekomastili lezyonların 15'i fibröz, 5'i florid ve 12'si mikst tip olarak izlendi (Şekil 1). Olguların 3'ünde fibrokistik değişiklikler/ apokrin metaplazi, mikropapiller hiperplazi, 2'sinde usual duktal hiperplazi ve psödoanjiyomatöz stromal hiperplazi bulguları saptand.

57 yaşında klinik öyküsünde obezite ve ensede lipomatozis bulguları mevcut olan hastanın sağ ve sol memede lipomatozis izlendi.

Pilomatriksoma hasta yaşları 37, 38 ve 43 olup, hastalar 

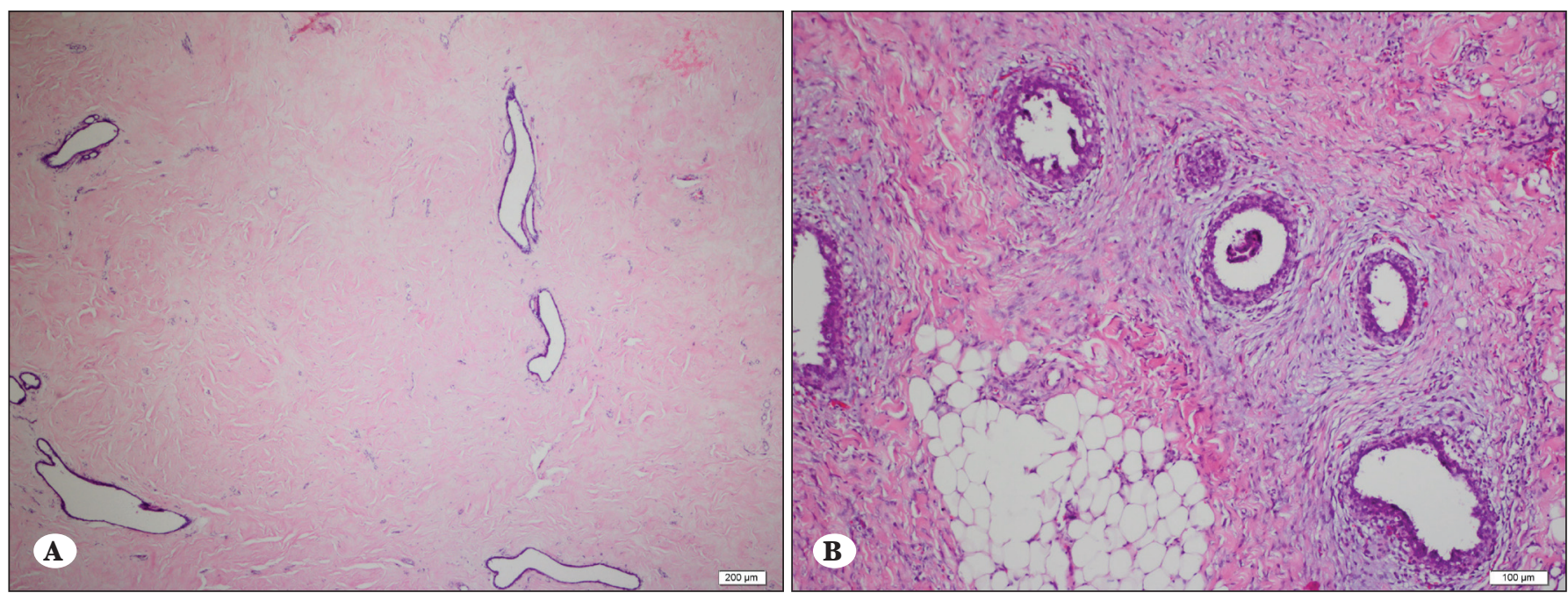

Şekil 1: Jinekomasti. A) Fibröz tip jinekomasti, fibrotik stromada minimal prolifere duktuslar (HE, x40) B) Florid tip jinekomasti, fibroblastik stromada prolifere duktuslarda tomurcuklanmaklar izlenmektedir. (HE, x100).
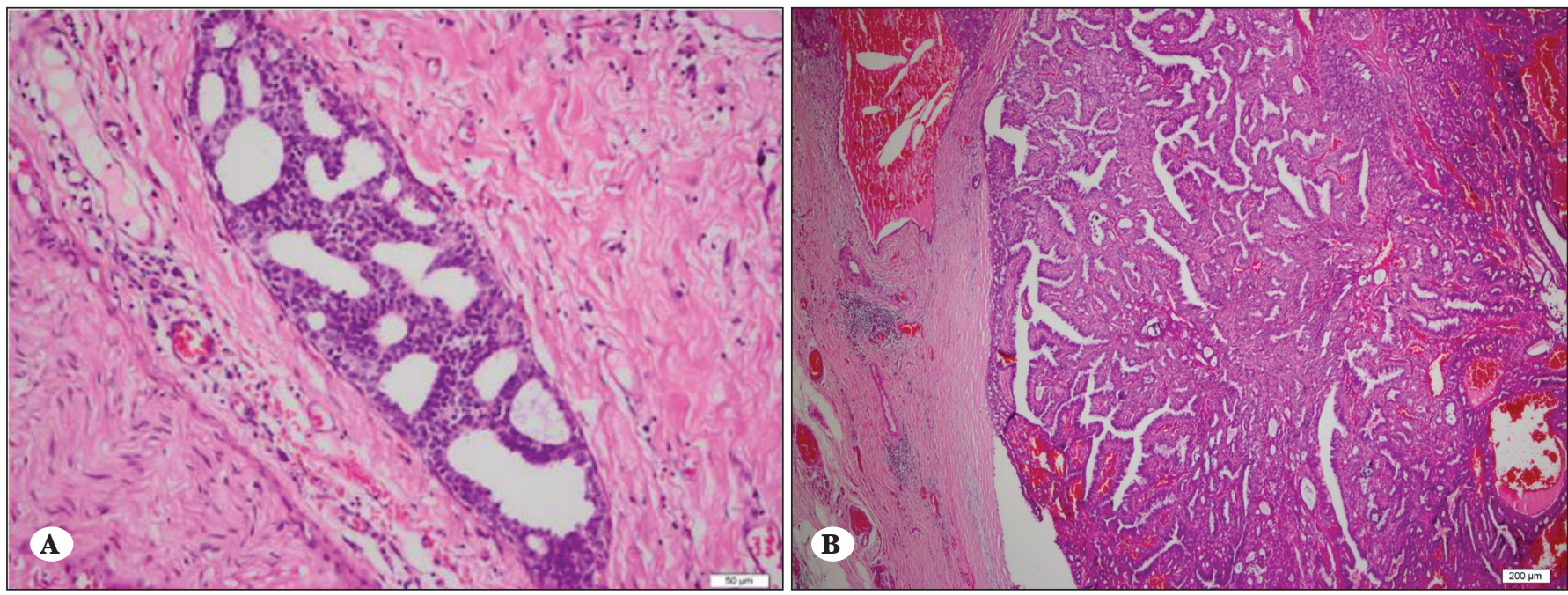

Şekil 2: A) Atipik duktal epitelyal hiperplazi: Genişlemiş duktus içerisinde düzensiz fenestrasyonlar gösteren monoton görünümde epitelyal proliferasyon (HE, x200) B) İntraduktal papillom: Genişlemiş duktus içerisinde fibrovasküler kora sahip papiller yapıların epitelyal ve myoepitelyal hücreler ile döşeli görünümde olduğu izlenmektedir. (HE, x40).

sağ memede ele gelen kitle şikayeti nedeniyle genel cerrahi kliniğine başvurdu. Radyolojik incelemede BIRADS 4 olarak değerlendirildi ve malignite yönünden şüpheli olması nedeniyle kitle total olarak çıkarıldı. Hastalardan birinde hiperlipidemi öyküsü saptandı.

İntraduktal papillom olgusu 53 yaşında, sağ meme retroareolar 1 yıldır var olan kitle nedeniyle opere edildi. Hastanın klinik öyküsünde yüzeyel venöz tromboz ve kolesterol/ trigliserid yüksekliği mevcuttur. Histopatolojik incelemesinde $5 \mathrm{~cm}$ uzun çaplı lezyonda atipi ve malignite saptanmadı, lezyon dışı meme parankiminde atipik duktal epitelyal hiperplazi, papiller apokrin değişiklikler gibi proliferatif meme lezyonları izlendi (Şekil 2).

İnvaziv meme karsinomu tespit edilen 6 hastadan en küçük yaş 38, en büyük yaş 75 olmak üzere, hastaların 5’i
40 yaş üzerindedir. Tüm olgular tek taraflı ve 4'ü sağ 2'si sol memede lokalizedir. Tüm olgular ağrısız retroareolar kitle şeklinde prezente olmuş ve ülser ya da meme cildine tümöral infiltrasyon mevcut değildi. Hastaların klinik öykülerinde hipertansiyon, hiperlipidemi, kronik arter hastalı̆̆ı, tip II diyabet ve obezite tespit edildi (Tablo I). Inncelenen olguların 3'de aksiller lenf nodu tutulumu izlendi. Tümör çapları 1,1- 3,0 cm arasında değişmektedir. Tüm meme karsinomları invaziv duktal karsinom tipinde olup, grade II (3 olgu) ve grade III (3 olgu) olarak saptand. Histolojik incelemede kadın meme karsinomlarına benzer görünümde desmoplastik stroma, trabeküller, kordonlar ve solid adalar şeklinde parankim infiltrasyonu ve eşlik eden duktal epitelyal hiperplazi bulguları izlendi (Şekil 3). İmmünhistokimyasal olarak tümü ER pozitif, PR ile 4 olgu, AR (Şekil 4) ile 4 olguda değişen derecelerde pozitiflik izlendi. 
Tablo I: Erkek meme kanserlerinde prognostik ve prediktif belirteçlerin histolojik ve immünhistokimyasal olarak değerlendirilmesi.

\begin{tabular}{|c|c|c|c|c|c|c|c|c|c|}
\hline Yaş & Klinik öykü & $\begin{array}{l}\text { Tümör } \\
\text { çapı (cm) }\end{array}$ & Lokalizasyon ER (\%) & PR (\%) & CerbB2 & $\mathbf{A R}(\%)$ & Ki-67 & Grade & Luminal \\
\hline 38 & - & 1.1 & Sol & negatif & negatif & negatif & 2 & 2 & $\mathrm{~A}$ \\
\hline 45 & Obezite, & 3.0 & Sol & 95 & negatif & 80 & 1 & 2 & A \\
\hline 56 & - & 1.9 & Sağ & 60 & negatif & 80 & 4 & 2 & A \\
\hline 62 & $\begin{array}{c}\text { Obezite, } \\
\text { Hiperlipidemi }\end{array}$ & 2.8 & $\mathrm{Sag}$ & negatif & negatif & 90 & 30 & 3 & B \\
\hline 75 & $\begin{array}{l}\text { Kronik arter } \\
\text { hastalı̆̆l, Tip } \\
2 \text { Diyabet, } \\
\text { Hipertansiyon }\end{array}$ & 2.2 & Sağ & 30 & negatif & 70 & 30 & 3 & B \\
\hline 75 & $\begin{array}{c}\text { Obezite, } \\
\text { Tip } 2 \text { Diyabet, } \\
\text { Hipertansiyon }\end{array}$ & 2.5 & Sağ & 40 & negatif & 60 & 25 & 3 & B \\
\hline & & & $2=\frac{50 u m}{2}$ & 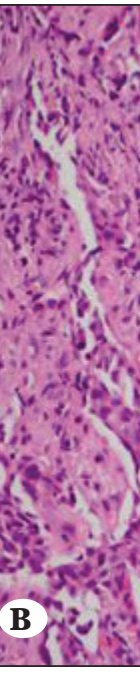 & & 12.20 & & $2=$ & 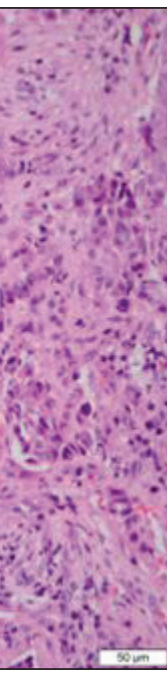 \\
\hline
\end{tabular}

Şekil 3: A) Düşük gradeli invaziv duktal karsinom: desmoplastik stromada irregüler tübül yapıları gösteren orta derecede pleomorfik hücreler izlenmektedir. (HE, x200) B) Yüksek gradeli invaziv karsinom: desmoplastik stroma ve solid adalar şeklinde belirgin pleomorfizm gösteren atipik hücreler izlenmektedir. (HE, x200).
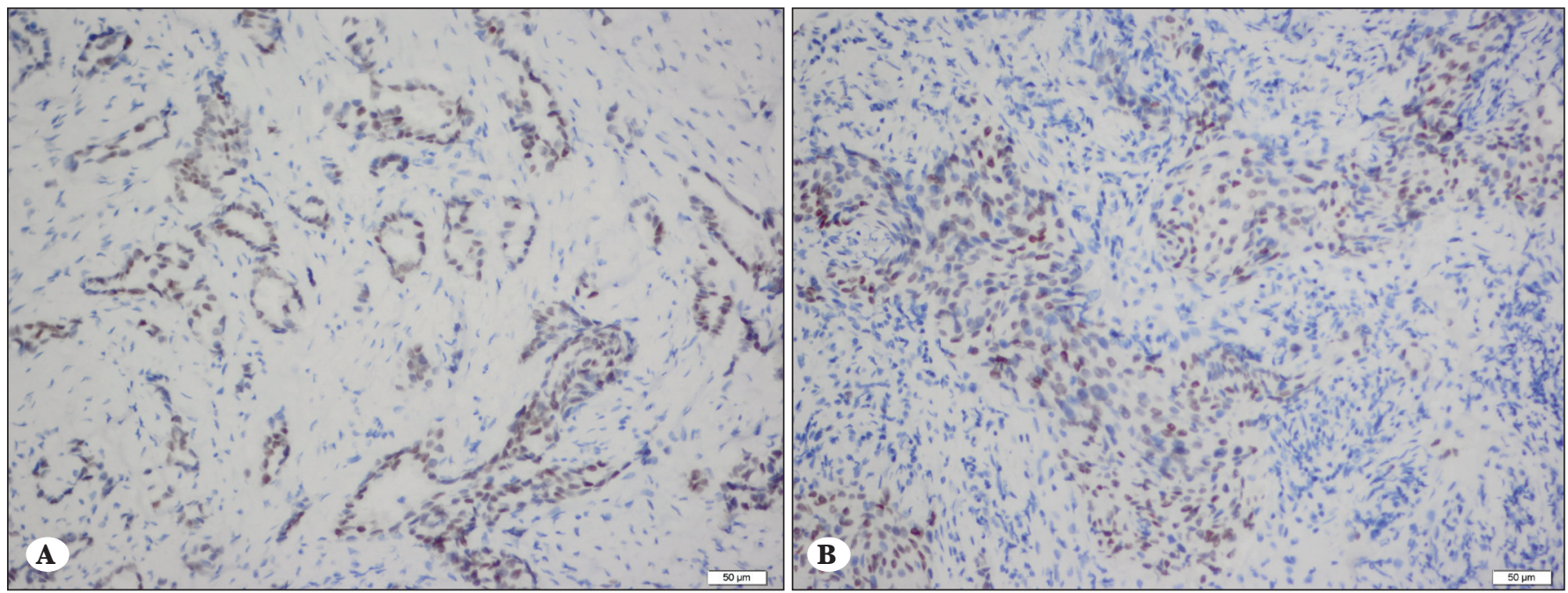

Şekil 4: Androjen reseptör pozitifliği A) Düşük gradeli karsinom. (HE, x200) B) Yüksek gradeli karsinom (HE, x200). 
CerbB2 ile boyanma saptanmadi. Ki-67 proliferasyon indeksi orta gradeli tümörlerde $\% 5$ 'in altında iken, yüksek gradeli tümörlerde \%30 olarak saptandı (Tablo I). Illeri yaş hastalar (60 yaş üzeri) Grade III ve ki-67 proliferasyon indeksi yüksek Luminal B olarak prezente olur iken, daha genç hastalar Grade II ve ki-67 proliferasyon indeksi düşük Luminal A olarak tespit edilmiştir.

\section{TARTIŞMA}

Erkek meme lezyonları oldukça nadirdir. Jinekomasti erkek memesinin en s1k görülen lezyonu olup erkeklerin \% 57'sinde görülen yaygın bir bulgudur. Histolojik olarak stromal elemanların ve duktal yapının hiperplazisi ile karakterizedir. Hem fizyolojik (hipogonadizm, östrojen-androjen imbalansi) hem de fizyolojik olmayan (ilaçlar, bitkisel ürünler) nedenlerden kaynaklanır. Sıklıkla püberte yaşında veya yaşlılarda görülür (12). Bizim çalışmamızda da en sık izlenen lezyon jinekomastidir ve 40 yaş altı gençlerde daha sik saptand.

Pilomatriksomalar kıl foliküllerinin pluripotent prekürsör matriks hücrelerinden gelişen en sık baş-boyun bölgesinde görülen nadir rastlanan kutanöz tümörlerdir. Meme pilomatriksomaları 100.000 de 1 insidans ile son derece nadirdir. Bu vakaların çoğu genellikle meme neoplazmları olarak yanlış teşhis edilir. Etyolojisinde travma ve enfeksiyonun rol oynayabileceği belirtilmekle beraber tam olarak bilinmemektedir ve kıl foliküllerinin siklusundaki bir duraksama sonucu pilomatriksomaların gelişebileceği bildirilmektedir (13). Çalışmamızda radyolojik olarak BIRADS 4 malignite şüphesi nedeniyle eksize edilen 3 vaka saptanmış olup, meme kitlelerine yaklaşımda ayırıcı tanıda pilomatriksomanın da akılda tutulması önemlidir.

İntraduktal papillom, kadın memesinin aksine erkeklerde nadir görülür ve bugüne kadar literatürde oldukça az sayıda vaka bildirilmiştir. İntraduktal Papillom olguların küçük bir kısmı karsinoma progresyon gösterdiği için tanı ve tedavi amacıyla mutlaka cerrahi eksizyon yapılmalıdır(14). Bizim olgumuzda intraduktal papilloma eşlik eden atipik duktal epitelyal hiperplazi izlenmiş olup lezyon geniş olarak eksize edilmiş ve malignite saptanmamıştır.

Meme kanseri, erkek ve kadınları etkileyen bir hastalıktır ve cinsiyetler arasında bilinen en önemli fark insidanstır. Erkek meme kanseri, erkeklerde tüm kanserlerin \%1'inden azını ve tüm meme kanserlerin yaklaşık \%1'ini oluşturmaktadır (15). Meme kanseri; benzer klinik geçmişleri ve benzer histomorfolojiye sahip olsa bile tedaviye verdikleri cevaplar farklılık gösterebilir. Bu özellik histolojik olarak benzer tümörler arasındaki moleküler gen ekspresyon profilinin farklılığı ile tanımlanabilir (16). Artan kanıtlar, erkek meme kanseri ile kadın meme kanseri arasında moleküler alt tiplerinin farklı olabileceğini göstermektedir $(8,17)$. Bu nedenle erkek meme kanseri kadın meme kanserinden ayrı bir hastalık olarak kabul edilmeli ve farklı tedavi uygulanması gerekliliği doğmaktadır.

Uluslararası erkek meme kanser programının yapmış olduğu 20 ylllık retrospektif çalışmada erkek meme kanseri karakterize edilmiştir. Hastaların çoğunda $\mathrm{ER}, \mathrm{PR}$ ve AR pozitif, CerbB2 negatif izlenmiş olup Luminal B benzeri $(\% 48,6)$ ve Luminal A benzeri $(\% 41,9)$ olarak tespit edilmiştir. Human Epidermal Growth Factor 2 (HER2) pozitifliği ve triple negatiflik daha önce raporlanan vakalar ile uyumlu olarak çok az olguda gözlenmiş ve erkek memesinde HER2 pozitif veya triple negatif tanısında, tedavi öncesinde ikinci bir patolojik inceleme önerilmektedir (18). Bizim çalışmamıda literatür ile uyumlu Luminal A benzeri ve Luminal B benzeri eşit oranda izlenmiştir. İleri yaş hastalar Luminal B, daha genç hastalar Luminal A olarak saptanmıştır. ER, $P R$ ve AR ile değişen derecelerde pozitiflik gözlenmiş ve HER2 pozitifliği izlenmemiştir. André ve ark.larının yaptığı çalışmada erkeklerde izlenen en sık histolojik tip spesifiye edilemeyen invaziv karsinom olarak raporlanmıştır (19). Çalışmamızda literatür ile uyumlu olarak tüm olgular spesifiye edilemeyen invaziv karsinom olarak saptanmıştır.

Erkek meme kanserlerinde; hormonal tedavi (ER ve PR pozitif), HER2 pozitif monoklonal antikorlar (Herceptin), cerrahi ve radyoterapi gibi kadın meme kanserlerinin tedavi protokolü uygulanmaktadır. Son yıllarda meme kanserinde AR ekspresyonu ile ilgili araştırmalar ve AR antagonistlerinin meme karsinomları üzerine etkisi araştırılmaktadır (20). AR meme kanseri tedavisinde yeni bir hedef olarak dikkat çekmektedir. Erkek meme kanserlerinde CerbB2 pozitifliği çok ender olması nedeniyle HER2 pozitif monoklonal tedavi nadir uygulanmaktadır. AR pozitifliğinin yüksek olmasi, erkek meme kanseri tedavisinde AR antagonistlerin kullanılması alternatif bir seçenek olarak düşünülebilir.

\section{SONUÇ}

Erkeklerde meme kanseri açısından farkındalık olmaması ve tanısal gecikmeler nedeniyle daha ileri evrede tanı almakta ve kadınlara oranla prognozu daha kötü seyretmektedir. Erkek meme kanserine yönelik güncel tedavi ve prognostik parametrelerin geliştirilmesi için çok merkezli çalışmalar yapılmalıdır. Erkeklerde meme lezyonlarına karşı farkındalığın artması ve malign lezyonların erken yakalanması için iyi bir tıbbi eğitimin gerekli olduğuna inanıyoruz.

\section{YAZAR KATKI}

Fikir/kavram: P.C., S.C.

Tasarım: P.G., İ.B.

Denetleme/Danışmanlık: P.C., S.C.

Veri toplama/ veya İşleme: P.C., I.B.

Analiz veya yorum: P.C., S.C. 
Kaynak taraması: P.C., I.B.

Makalenin yazımı: P.C.

Eleştirel inceleme: S.H.

Etik komite onayı: Bu çalışma için Etik Komite Onayı Sağlık Bakanlığı Ankara Eğitim ve Araştırma Hastanesi Klinik Araştırmalar Etik Kurul Başkanlığından E-20 sayılı 250 no'lu çalışma olarak 21.04.2020 tarihinde alınmıştır.

\section{KAYNAKLAR}

1. Mansel R, Webster D, Sweetland H. The male breast. Benign disorders and diseases of the breast. 3era edicion. Elsevier 2009; 25-272.

2. Mieritz MG, Christiansen $\mathrm{P}$, Jensen MB, Joensen UN, Nordkap L, Olesen IA, Bang AK, Juul A, Jørgensen N. Gynaecomastia in 786 adult men: clinical and biochemical findings. Eur J Endocrinol 2017; 176(5): 555566.

3. Bowers SP, Pearlman NW, Mclntyre RCF, Finlayson CA, Huerd S. Cost effective management of gynecomastia. American Journal of Surgery 1998; 176 (6): 638-641.

4. Schanz S, Schreiber G, Zitzmann M, Krapohl BD, Horch R, Köhn FM. S1 guidelines: Gynecomastia in adults. JDDG 2017; 4: 465-472.

5. Johansen Taber KA, Morisy LR, Osbahr 3rd AJ, Dickinson BD. Male breast cancer: risk, diagnosis, and management (Review). Oncol Rep 2010; 24: 1115-1120.

6. White J, Kearins O, Dodwell D, Horgan K, Hanby AM, Speirs V. Male breast carcinoma: increased awareness needed. Breast Cancer Res 2011; 13(5): 219.

7. Humphries MP, Jordan VC, Speirs V. Obesity and male breast cancer: provocative parallels. BMC Medicine 2015; 13: 134.

8. Anderson WF, Jatoi I, Tse J, Rosenberg PS. Male breast cancer: a population-based comparison with female breast cancer. J Clin Oncol 2010; 28(2): 232-9.

9. Thomas DB, Jimenez LM, McTiernan A, Rosenblatt K, Stalsberg H, Stemhagen A, Thompson WD, McCrea Curnen MG, Satariano W, Austin DF, Greenberg RS, Key C, Kolonel LN, West DW. Breast cancer in men: risk factors with hormonal implications. Am J Epidemiol 1992; 135(7): 734-48.

10. Ruddy KJ, Winer EP. Male breast cancer: risk factors, biology, diagnosis, treatment, and survivorship. Ann Oncol 2013; 24(6): 1434-43.

11. Voinea OC, Cirstoiu MM, Ion D, Sajın M, Dumitru AV, Patrascu OM, Jinga DC, Nica AE. Histology of Male Breast Lesions. Series of Cases and Literature Review. MAEDICA - a Journal of Clinical Medicine 2018; 13(3): 196-201.
Çıkar çatışması: Makalenin yazarları arasında çıkar çatışması bulunmamaktadır.

Finansman veya Mali Destek: Bu çalışmada finansman veya mali destek alınmamıştır.

12. LadizinskiB, Lee KC, Nutan FNU, Higgins HW, Federman DG. Gynecomastia: etiologies, clinical presentations, diagnosis, and management. South Med J 2014; 107(1): 44-9.

13. Kapoor A, Narayanan R, Tandon A, Santosh AK. Pilomatricoma: An unusual cause of lump in a male breast. J Clin Ultrasound 2018; 46(3): 209-211.

14. Vagios I, Nonni A, Liakea A, Constantinidou A, Kontos M. Intraductal papilloma of the male breast: a case report and review of the literature. Journal of Surgical Case Reports 2019; 2: 1-4.

15. Giordano SH, Cohen DS, Buzdar AU, Perkins G, Hortobagyi GN. Breast carcinoma in men: a populationbased study. Cancer 2004; 101(1): 51-57.

16. C Perou, T Sorlie, MB Eisen, Van de Rijn M, Jeffrey SS, Rees CA, Pollack JR, Ross DT, Johnsen H, Akslen LA, Fluge Ø, Pergamenschikov A, Williams C, Zhu SX, Lønning PE, Børresen-Dale AL, Brown PO, Botstein D. Molecular portraits of human breast tumors. Nature 2000; 406: 747-752.

17. Weir J, Zhao YD, Herman T, Algan O. Clinicopathologic features and radiation therapy utilization in patients with male breast cancer: a national cancer database study. Breast Cancer 2018; 12: 1178223418770687.

18. Cardoso F, Bartlett JMS, Slaets L, Van Deurzen CHM, Van Leeuwen-Stok E, Porter P, Linderholm B, Hedenfalk I, Schröder C, Martens J, Bayani J, Van Asperen C, Murray M, Hudis C, Middleton L, Vermeij J, Punie K, Fraser J, Nowaczyk M, Rubio IT, Aebi S, Kelly C, Ruddy KJ, Winer E, Nilsson C, Lago LD, Korde L, Benstead K, Bogler O, Goulioti T, Peric A, Litière S, Aalders KC, Poncet C, Tryfonidis $\mathrm{K}$, Giordano SH. Characterization of male breast cancer: results of the EORTC 10085/TBCRG/BIG/NABCG International Male Breast Cancer Program. Ann Oncol 2018; 29(2): 405-417.

19. André S, Pereira T, Silva F, Machado P, Vaz F, Aparício M, Silva GL, Pinto AE. Male breast cancer: Specific biological characteristics and survival in a Portuguese cohort. Mol Clin Oncol 2019; 10(6): 644-654.

20. Arce-Salinas C, Riesco-Martinez MC, Hanna W, Bedard P, Warner E. Complete response of metastatic androgen receptor-positive breast cancer to bicalutamide:case report and review of the literature. J Clin Oncol 2016; 34(4): e21-4. 